\title{
EGFR NM_005228.3:c.2254_2277del24
}

National Cancer Institute

\section{Source}

National Cancer Institute. EGFR NM 005228.3:C.2254 2277del24. NCI Thesaurus. Code C98578.

A deletion of 24 nucleotides from the coding sequence of the EGFR gene from position 2254 through 2277. 